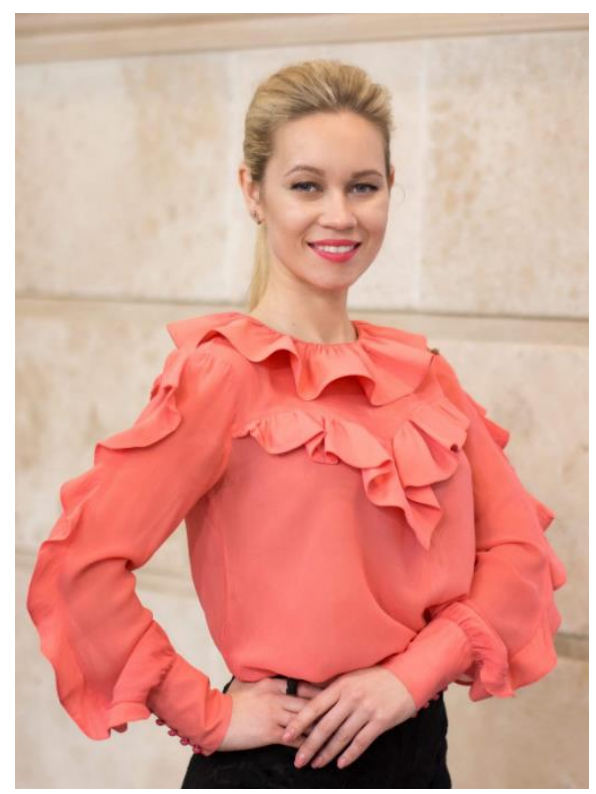

\section{OVCHARENKO}

Iuliia S.,

Ph.D. in History,

Assistant of the physical department of

National Technical University

«Kharkiv Polytechnic Institute»

ovcharenko.iuliya12@gmail.com

(Kharkiv city, Ukraine)

\title{
THE INSTITUTIONALIZATION OF THE SCIENTIFIC RESEARCH OF CRYOPHYSICS IN UKRAINE (THE 30 s OF THE 20 th cent. - THE BEGINNING OF THE 21 th cent.)
}

In the article, the process of institutionalization of research work on the field of low-temperature physics in Ukraine was reconstructed. It was established that the determining trend in the development of low-temperature physics was the creation of the specifically targeted research laboratories and institutes, which made it possible to deepen research work. It is determined that in the '30s of the 20th century a network of scientific centers for research in the field of cryophysics began to appear. It was shown that the first cryogenic laboratory in the USSR and the fourth in the world was organized by I.V. Obreimov in Ukrainian Institute of Physics and Technology, which became the basis for scientific research on the field of cryophysics in Ukraine. The contribution of Ukrainian scientists and scientific groups to the organization of science and stable social structure was specified. The research is based on the use of a complex of general scientific and historical methods.

Keywords: institutionalization, cryophysics, research work, research laboratory, research.

\section{ІНСТИТУЦІОНАЛІЗАЦІЯ НАУКОВИХ ДОСЛІДЖЕНЬ У ГАЛУЗІ КРІОФІЗИКИ В УКРАЇНI (30-ті pp. ХХ ст. - ПОЧАТОК ХХІ ст.)}

У статті вперше реконструйовано проиес інституиіоналізаиї науководослідної роботи з напряму низькотемпературної фізики в Україні. Встановлено, що визначальною тенденцією розвитку фізики низьких 
температур було створення вузькогалузевих дослідних лабораторій та інститутів, що дало змогу поглибити науково-дослідну роботу. Визначено, що y 30-х рр. ХХ ст. почала формуватися мережа наукових центрів для досліджень y галузі кріофізики. Показано, що перша кріогенна лабораторія в СРСР та четверта у світі була організована в УФТІ І.В. Обреїмовим, яка стала базою для розгортання наукових досліджень з кріофізики в Украӥні. Конкретизовано внесок вітчизняних учених та наукових колективів у процес організації науки у стійку соціальну структуру. Дослідження трунтується на використанні комплексу загальнонаукових та історичних методів.

Ключові слова: інституціоналізація, кріофізика, науково-дослідна робота, дослідна лабораторія, дослідження.

\section{ИНСТИТУЦИОНАЛИЗАЦИЯ НАУЧНЫХ ИССЛЕДОВАНИЙ В ОБЛАСТИ КРИОФИЗИКИ В УКРАИНЕ}

\section{(30-е гг. ХХ в. - НАЧАЛО ХХІ в.)}

В статье впервые реконструировано процесс институционализации научно-исследовательской работь в области низкотемпературной физики в Украине. Установлено, что определяющей тенденцией развития физики низких температур стало создание узкоотраслевых исследовательских лабораторий и институтов, что позволило расширить научно-исследовательскую работу в этой области. Определено, что в 30-х г2. ХХ в. начала формироваться сеть научных центров для исследований в области криофизики. Показано, что первая криогенная лаборатория в СССР и четвертая в мире была организована в УФТИ И.В. Обреимовым, которая стала базой для развертывания научных исследований в области криофизики в Украине. Конкретизирован вклад отечественных ученых и научных коллективов в процесс организаџии науки в устойчивую сочиальную структуру. Исследование основывается на использовании комплекса общенаучных и исторических методов.

Ключевые слова: институчионализация, криофизика, научноисследовательская работа, исследовательская лаборатория, исследования.

In the modern world of rapid scientific and technological progress, an important part in determining the potential of Ukraine as a competitive state is research in fundamental sciences that have not only theoretical but also applied character. Physics is one of the important natural sciences that influences dynamic scientific and technological progress. In particular, this applies to the field of low-temperature physics. Application of cryophysics makes it possible to achieve significant results in the most progressive branches of science, industry, agro-industrial complex, medicine, 
construction industry, and others. The basis for the intensification of research work on the direction of cryophysics is institutionalization.

Some aspects of the institutionalization of research on the direction of cryophysics in Ukraine were disclosed in the scientific works of A. Tanshina, V.M. Varyukhin, V.I. Kamenev, V.M. Krivoruchka, V.I. Gryshchenko, V.I. Garbuz [1; 14; 17; 19]. However, the authors did not aim to reconstruct the process of institutionalization. The methodological bases of the research are based on the use of the principles of historicity, objectivity, comprehensiveness and general scientific principles of historical knowledge, which made it possible to objectively determine the most effective directions and ways of solving the problem.

As a result, the internal logic of the development of the scientific branches of physics and the transition to the professional level of activity is the process of institutionalization of science, which involves the adoption of administrative decisions on the creation of scientific institutions, research centers, laboratories, etc.

In the article, the process of institutionalization of research work on the direction of cryophysics in Ukraine has reconstructed [Pic. 1]. It was established that the determining trend in the development of low-temperature physics was the creation of narrow-band research laboratories and institutes, which made it possible to deepen research work. It was determined that for decentralization of science in the USSR a decision was made on the organization of physical centers in the province because before the beginning of the 20th century in the USSR there were only two centers of physical science - Leningrad (now is St. Petersburg) and Moscow. In 1928 A. F. Joffe decided to allocate the same institutes for Tomsk, Kharkov, Dnepropetrovsk and Sverdlovsk (now is Yekaterinburg) from the Physical-Technical Institute of Leningrad. This year, the construction of the Ukrainian Institute of Physic and Technology (UIPT) in Kharkov started, with financial support from the Supreme Council of the National Economy of the USSR and Ukraine, and it was completed in a short period - 9 months. I.V. Oreimov, the first director of UIPT, laid the strategic direction of scientific research at the institute, which allowed for a short time to obtain significant results in the field of theoretical physics [1]. 


\section{The institutionalization of research on the direction}

\section{of cryophysics in Ukraine}

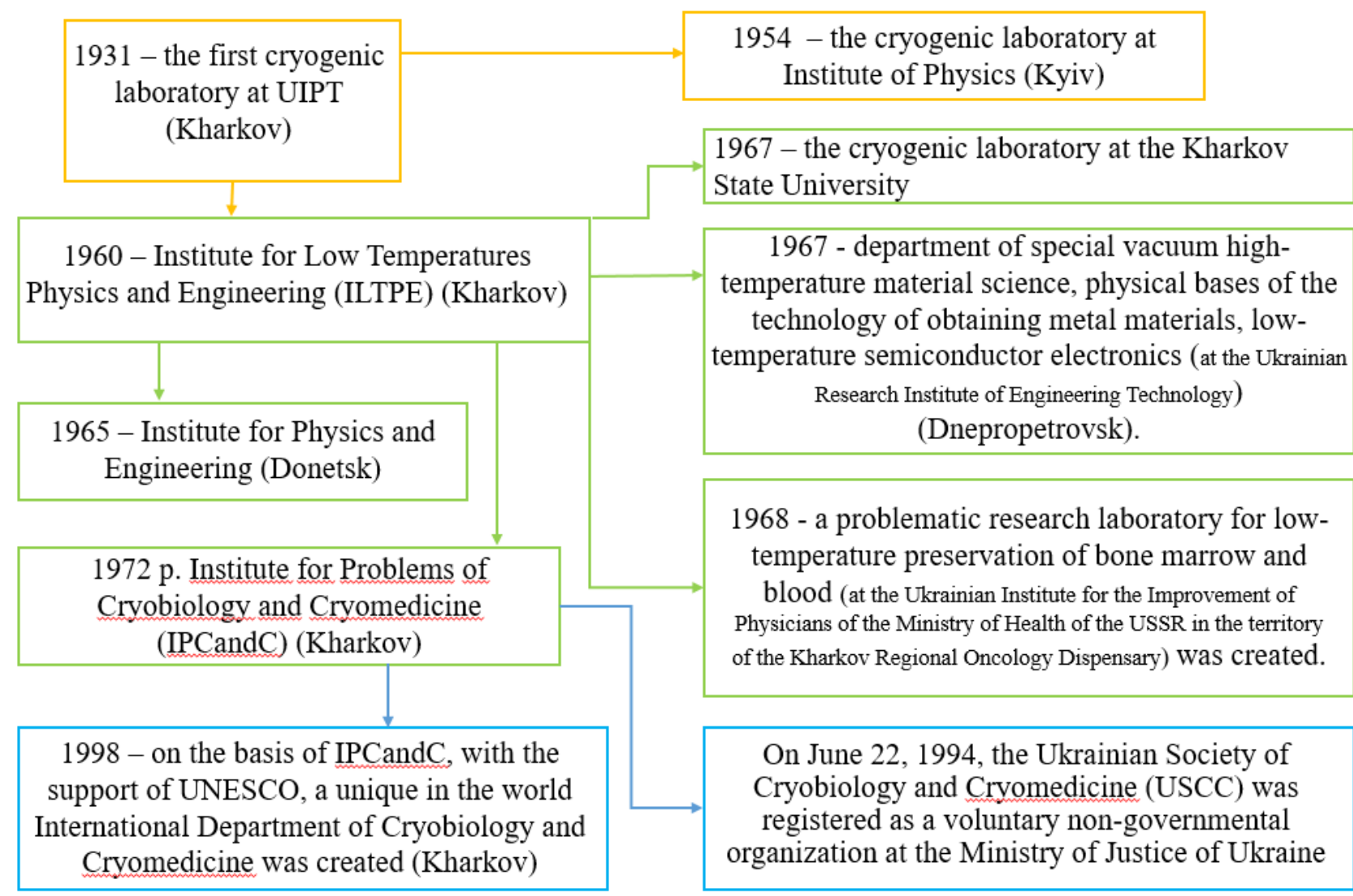

The first cryogenic laboratory in the USSR and the fourth in the world, subsequently headed by L.V. Shubnikov, was organized by I.V. Oreimov. The institute became the basis for the deployment of scientific researches on cryophysics in Ukraine. From the first days of the organization in the laboratory, the properties of liquefied and solidified gases (nitrogen, argon, oxygen, methane) were investigated. Scientists of the cryogenic laboratory of UIPT, the first in the USSR, began to study the properties of helium. For experimental research, an experimental deep-cooling station was constructed. Scientists of the institute initiated in the USSR conducting research on the topic «atomic nucleus» $[1 ; 2 ; 3]$.

By the beginning of the 1950s, there were only three cryogenic laboratories in the USSR at the Institute of Physics Problems (Moscow), UIPT (Kharkiv) and the Institute of Physics (Tbilisi). With the help of UIPT in 1953, a cryogenic laboratory was organized at the Physics and Technical Institute of Leningrad and in 1954 at Institute 
of Physics in Kyiv. The forces of scientists were scattered in the small labs of physical institutes and performed only auxiliary functions.

In the late 1950s, one of the most promising directions was the study of space. At that time, the physical science developed dynamically, in particular, physics of lowtemperature played a significant role in the scientific and technological progress of the country. Current issues at that time were the exploration and development of space, the design of missiles, guided shells and other space technology, as well as mechanisms and devices for them. These tasks were due to the fact that space-based aircraft and materials from which they were made should operate in a radically different environment from the physical characteristics. Much of the information available at the time contained information only on the behavior of materials in terrestrial conditions. Therefore, the preparation of missiles, the complexity of conducting remote experiments made it necessary to study the behavior of materials in conditions simulating space. Consequently, it was necessary to simulate space in laboratory conditions. In addition, using methods and instruments based on the use physics of low-temperature, questions were asked about their application in space exploration, metal strength, superconductivity, medicine, biology, agriculture, and others. Much of the information available at the time contained information only on the behavior of materials in terrestrial conditions. A wide range of applications of the results of cryogenic physics studies required much more focus on the development of the most relevant and important issues in this field. Therefore, at the beginning of 1959 B.I. Verkin and A.A. Galkin began to prepare the scientific base for the future institution [4; 5]. With the support of Director of the Institute of Radiophysics and Electronics (IRE) O.Ya. Usikov, scientists were able to get premises for the first laboratory of the future institute, which was named «Laboratory B». Also, with the active help of S.P. Capitza, scientists received funding of about 2 million rubles. The money was transferred to the IRE account because Institute for Low Temperatures Physics and Engineering (ILTPE) itself had not officially existed. But scientists have already begun active research in a small laboratory. During 1959 intensive work was 
conducted, scientists worked in two directions: the realization of the received funding and the expectation of a positive decision on the organization of the institute [6;7].

The two great powers in the struggle for leadership were the Soviet Union and the United States of America (US). Academic S.P. Korolev, who was one of the pioneers in rocketry and the prominent designer of the first artificial satellites in the USSR, raised the question of a vacuum test of friction knots on the topic «Star». As noted above, even before making a positive decision on the existence and construction of premises for the institute, B.I. Verkin, together with the team, decided to start research on the problems of vacuum testing of friction units in a small laboratory, which the scientists managed to organize on their own. This would help draw the attention of the leadership of the Academy of Sciences of the USSR to a significant internal potential of scientists. At the same time, this topic could provide the organizers of the institute with significant material benefits and open the way to the possibility of a successful institution building. The first test installation with a cryogenic vacuum from the main gas pipe and DC motor, which has already worked in the Scientific-Research Institute of vacuum technology of S.A. Vekshinsky for 500 hours. As a result of the experiment, a bitter copper with graphite was obtained, which was a testimony to the processes of friction in the vacuum. To this experiment on friction in the vacuum, nothing was known and there was no vacuum material science. When S. P. Korolev learned of such an initiative from the side of the scientists, he was angry, but this important experience opened all the doors to the scientist. From that moment, a decision was made to direct the work of the institute and support its activities by the Central Committee of the CPSU. The management of ILTPE was entrusted with the organization of the vacuum research center and the development of vacuum and space materials [5].

Accordingly to the prospective plans for the development of science under the Decree of the Council of Ministers of the USSR №681 (May 11, 1960) and the Resolution of the Presidium of the Academy of Sciences of the USSR (May 13, 1960) made a decision on the establishment of a Institute for Low Temperatures Physics and Engineering (ILTPE) in Kharkov for the development of advanced scientific research in the field of physics of low-temperature and solving practical problems of the 
country's economic complex [8]. The Council of Ministers of the USSR, by its Decree №876-375 (September 23, 1961), assigned the main institute in the field of cryogenic rocket technology to ILTPE. The main task of the newly created institute was the carrying out of research and development works aimed at improving systems with low boiling fluids used in special objects and spacecraft [11;12].

On the basis of the study of monographic works of scientists, it was established that in ILTPE studies were carried out in a wide range of fundamental and applied directions, such as: electronic properties of normal metals, fundamental applied superconductivity, high-temperature superconductivity, transport processes in materials and systems, structure and mechanical properties of materials at low temperatures, properties of cryogenic crystals and liquids, molecular biophysics, physics and technology of ultra-high temperatures [10].

Beginning from the 1960s, experimental research on laboratory simulation of space conditions was developed at the Institute. Led by B.I. Verkin, a team of scientists formulated the physical basis for laboratory simulation of the space environment and designed high-vacuum cameras simulating the cosmic environment and radiation on the basis of which integrated research on structural materials was carried out under the influence of low temperatures and space conditions. Scientists have created a comprehensive simulator that is designed to study the properties of materials and coatings under the influence of the main factors of outer space. Currently, the modifier is used in the interests of the National Space Agency of Ukraine, its modified versions work at the Institute of the German Aerospace Agency and the Harbin Polytechnic Institute in China. It should also be noted, that in 1974 by I.C. Janson was discovered a new method of microcontact spectroscopy, which is now widely used in leading world laboratories to study the interaction of conduction electrons with various types of quasiparticle excitations in metals and alloys. In 1987, for the discovery and development of this method, the scientist was awarded Hewlett-Packard Award of the European Physical Society. Now the institute is developing new directions for scientific research: obtaining and researching carbon nanomaterials (fullerenes, nanotubes, etc.). 
In 1965 in Donetsk for the theoretical and experimental development of problems of solid state physics, Donetsk Institute for Physics and Engineering named after A. A. Galkin Academy of Sciences of the Ukrainian SSR (DonIPE) was established to provide further technological progress in the metallurgical, coal, engineering industry of the Donbas. The organizer of the institute and its first director was the academician of the Academy of Sciences of the Ukrainian SSR A. A. Galkin. Close cooperation with ILTPE provided an opportunity to master the production of cryogenic liquids in a short time, which allowed DonIPE to develop solid-state research and comprehensive research on substances in extreme conditions (low temperatures, high pressures, strong magnetic fields, etc.).

As the analysis showed, scientists of the Institute received a number of fundamental scientific results of world significance: the discovery of a fundamentally new physical phenomenon of the intermediate state in antiferromagnets; development of the theory of excitons, kinetic properties of semiconductors, defects in crystals; detection and investigation of irreversible induction of a new magnetic state by a strong magnetic field; development of qualitatively new approach to obtaining physical information on tunnel characteristics of superconductors; the discovery of the phenomenon of doppler-phonon resonance in metals; detection of a new type of plastic deposition of mesoscopic level - formation of local dipole bends of a crystal lattice, and others.

In particular, in DonIPE, the basics of controlling the mechanical properties of highly azo-alloys with the use of high pressures have been developed; methods and regimes of forming of products from powders using cold isostatic pressing; new principles for the formation of nanostructured materials in massive samples, based on the use of high hydrostatic pressures and intense plastic deformations; complex of results of development of the most urgent areas of science: high-temperature superconductivity, physics of strongly correlated systems, nanophysics and nanotechnologies, magnetism, optics, structure and properties of materials, scientific foundations for the creation of new functional materials. Now the Institute develops the actual directions of physical science: nanophysics and nanoelectronics; physics and 
technology of perspective structural and functional materials; physics of crystals under extreme conditions $[13 ; 14]$.

In 1967, at the Kharkov State University, the cryogenic laboratory created by V. I. Hotkevich begins to work with its helium. At the Physics Department of the Kharkov State University, nitric and helium liquefaction stations were set up to intensify scientific research in the field of physics of low temperature. The cryogenic laboratory is the only one in higher educational establishments of Ukraine, which provides cryogenic fluids with the educational process and scientific research at the university $[9 ; 15]$.

Fundamental developments in the field of physics of low temperature, the discovery of new phenomena and processes in biology, medicine, chemistry, biotechnologies, cryogenic engineering and other branches of science gave impetus to the development of a new direction - cryobiology and cryomedicine. At that time, the urgent issue was the development of a network of banks for cryopreservation of blood. In September 1968 in Ukrainian Institute for the Improvement of Physicians of the Ministry of Health of the USSR the first problem research laboratory in Ukraine for low-temperature preservation of bone marrow and blood was established. The initiator of the creation and the first head of the laboratory was the founder of domestic cryobiology, corresponding member of the National Academy of Sciences of Ukraine, specializing in «Cryobiology», academician of medical sciences S. N. Pushkar. The laboratory was located on the territory of the Kharkov Regional Oncology Clinic, which contributed to the comprehensive treatment of patients [16].

The development of a new direction was also facilitated by the creation of the Institute for Problems of Cryobiology and Cryomedicine of the National Academy of Sciences of Ukraine (IPCandC) on the basis of the Laboratory of Phthisis in 1972. From 1972 to 1983 IPCandC was headed by S. N. Pushkar, who became the head of fundamental research aimed at studying mechanisms of cryosurgery and cryoprotection of cell structures, as well as numerous applied developments, many of which were introduced in medicine and the national economy. For example, for the first time in the world, scientists have developed quantitative theoretical models of 
phenomena and processes occurring at different stages of the cycle of low-temperature preservation of bone marrow, the tissue of the thyroid gland, developed new methods of treatment with the use of cold weather.

Cryobiotechnologies have been developed in IPCandC, which include preparation, cryopreservation and long-term preservation of cryoplactin, cells, and tissues (embryonic hematopoietic and nerve cells, early chorionic tissues, spleen, thyroid gland, kidneys, tubular and flat bones, cartilage and cerebral tissues, gonads, cells and tissues of other organs). Clinical approbation of cryoplactinin in the treatment of fetoplacental insufficiency, unprotected pregnancy, diabetes mellitus and its complications, infertility in men and women, pathological climax confirmed high therapeutic efficacy $[17 ; 18]$.

By V.I. Grishchenko together with his staff were developed methodological approaches to fertilization outside the body. For the first time in Ukraine in 1990, artificial insemination was carried out, which resulted on March 19, 1991, a child from the test tube was born. Patented in the USA, England, France, Germany and Japan the method of ultrafast freezing of sperm and human embryos was developed at the Institute [19].

Investigation of physiological processes with short-term effects of cold on the body contributed to the development of new non-pharmacological methods of correction of human pathological conditions, primarily disorders of the central nervous system. After prolonged experiments, scientists of IPCandC found that the short-term effect of low temperatures causes an increase in the power of the spectrum of the bioelectric activity of the heart, both in the ultralow and in the low-frequency range, while the changes are reversible with fast return to normal. Therefore, periodic procedures in the chamber of extreme cryotherapy at a temperature of -120 degrees Celsius increase the ability of the body to adapt through the activation of intracellular metabolic and transport processes, which leads to a decrease in destructive processes in the myocardium. The first chamber of extreme cryotherapy was constructed in the mid of 1990s in Kharkov in IPCandC with the participation of scientists from ILTPE $[17 ; 18 ; 20]$. 
With the initiative of the scientists of the Institute of PTILT at the higher educational establishments, new departments were organized: in 1977 the Department of Technical Cryophysics was created at the Kharkov Polytechnic Institute at the Faculty of Physics and Technology; In 1978, at the Kharkov State University, the Department of Biophysics was created at the Radiophysics Faculty.

On June 22, 1994, the Ukrainian Society of Cryobiology and Cryomedicine (USCC) was registered as a voluntary non-governmental organization at the Ministry of Justice of Ukraine. The main tasks of the organization were to promote the implementation of research work on the problems of cryobiology and cryomedicine in practice; exchange of information between members of the organization on questions of cryobiology and cryomedicine; development of the international community on matters within the statutory activities. October 18-20, 1995, the first congress of USCC was held in Kharkov [19]. In 1998, on the basis of the Institute, with the support of UNESCO, a unique in the world International Department of Cryobiology and Cryomedicine was created.

Consequently, the establishment of narrow-band research laboratories and institutes was the decisive trend in the development of cryophysics in Ukraine, which made it possible to deepen research work. The first cryogenic laboratory organized in UIPT became the basis for the deployment of scientific research in the field of lowtemperature physics in Ukraine. With the help of UIPT in 1954, a cryogenic laboratory was organized at the Institute of Physics in Kiev. In the late 1950s, physical science developed quite dynamically, in particular, the branch of low-temperature physics played a significant role in the country's scientific and technological progress. Therefore, in 1960, a special research institute - ILTPE in Kharkov was set up to develop promising scientific research in the field of cryophysics and to solve practical problems of the country's economic complex. In 1965 for theoretical and experimental development of the problems of solid-state physics and for the further development of technical progress in the metallurgical, coal, engineering industry of Donbass DonIPE was created, which, thanks to close cooperation with the ILTPE, was able to develop complex research of substances in extreme conditions. In order to develop a new 
direction - cryobiology and cryomedicine - on the basis of the laboratory of ILTPE in 1972 IPCandC was created.

\section{List of literature}

1. Таньшина А. Стоит напомнить : «Этого нигде не было». Украина, Харьков, УФТИ. East European journal of Physics. 2018. Vol. 5. № 1. Р. 81-101.

2. Лазарев Б. Г. Роль УФТИ в развитии исследований по физике и технике низких температур. Развитие криогеники на Украине. Киев : Наукова думка, 1978. C. $3-4$

3. Толок В. Т., Коган В. С., Власов В. В. Физика и Харьков. Харьков : Тимченко, 2009. 408 с.

4. 50 лет Харьковскому фізико-техническому институту. Київ : Наукова думка, 1978. 319 с.

5. Дмитренко И. М. Рождение института (очерки становлення ФТИНТ АН УССР). Харьков : Наукова думка, 1998. 138 с.

6. Б. И. Веркин, как мы его помним / ред. В. В. Еременко, И. В. Свечкарев. Киев : Наукова думка, 2007. 384 с.

7. Справки и информации отдела науки и учебных заведений, экономического отдела ЦК компартии Украины, Совета министров УССР, Донецкого обкома партии, АН УССР, др. организаций о работе парткома ФТИНТ АН УССР, института управления народным хозяйством, встречах работников донецкого обкома партии со студенческой молодежью и др. вопросам науки и образования (17.01.1984 - 25.12.1984) // Центральний державний архів громадських об’єднань України (ЦДАГО України). Ф. 1. Оп. 25. Спр. 2725. 40 арк.

8. Отчет ФТИНТ по капитальному строительству (1961р.) // Науковотехнічний архів Фізико-технічного інституту низьких температур ім. Б. І. Вєркіна НАН України (ФТІНТ НАН України). Ф. 1. Оп. 1. Спр. 15.8 арк.

9. Теоретическая физика на физическом факультете Харьковского университета / сост. В. В. Ульянов. Харьков : ХНУ им. В.Н.Каразина, 2009. $40 \mathrm{c}$.

10. История Академии наук Украинской ССР. Киев : Наук. думка, 1979. $835 \mathrm{c}$.

11. Документи і матеріали про створення ФТІНТ (доповідні записки АН УРСР, постанова Ради Міністрів УРСР, матеріали тощо) (1959-1960рр.) // Інститут архівознавства НБУВ (ІА НБУВ). Ф. 282. Оп. 1. Спр. 10. 17 арк.

12. Копии писем в ЦК КПСС, обкомам КПСС, КП Украины и другим организациям, письма, докладные записки обкомов КП Украины. Совнархозов, заводов и других организаций - о работе заводов, о капитальном строительстве и другим вопросам оборонной промышленности (1 августа1963 - 29 декабря 1963) // ЦДАГО України. Ф. 1. Оп. 24. Спр. 4924. 216 арк. 
13. Донецкому физико-техническому институту им. А. А. Галкина - 50 лет Донеикий физико-технический институт им. А. А. Галкина. URL : http://www.donfti.ru/main/donetskomu-fiziko-tehnicheskomu-institutu-im-a-agalkina-50-let/ (дата посещения : 23.05.2017).

14. Варюхин В. Н., Каменев В. И., Криворучко В. Н. Александр Александрович Галкин (1914-1982). К столетию со дня рождения. Физика низких температур. 2014. Т. 40. № 7. С. 735-736.

15. К истории криогенной лаборатории УФТИ-ННЦ «ХФТИ» (фрагменты). Национальный научный иентр ХФТИ. URL: https://www.kipt.kharkov.ua/itp/lazarev/2_2_3.html (дата посещения : 23.05.2017).

16. У истоков института проблем криобиологии и криомедицины. Міжнародний медичний журнал. 2017. № 3. С. 93-96.

17. Грищенко В. И. Достижения криобиологии и криомедицины во имя здоровья нации. Проблемы криобиологии. 2008. Т. 18. № 3. С. 269-274.

18. Прометеи в оковах: как Харьков был столицей технологий. Forbes Украина. URL : http://forbes.net.ua/magazine/forbes/1366094-prometei-v-okovahkak-harkov-byl-stolicej-tehnologij (дата посещения : 23.05.2017).

19. Гарбуз В. И. Хроника. Проблемы криобиологии. 1995. № 3. С. 55-56.

20. Отчет о научно-исследовательской деятельности ФТИНТ (1983р.) // Науково-технічний архів ФТІНТ НАН України. Ф. 1. Оп. 1. Спр. 1069. 194 арк.

\section{References}

1. Tanshina, A. (2018). Stoit napomnit : «Etogo nigde nebilo». Ukraina. Kharkov, UFTI [It is worth recalling : «This has never happened anywhere» Ukraine, Kharkov, UPTI]. East European journal of Physics [East European journal of Physics]. 5. 1. 81101. [in Russian].

2. Lazarev, B. G. (1978). Rol' UFTI v razvitii issledovanii po fizike i textike nizkih temperatur [The role of UPTI in the development of research in low-temperature physics and technology]. Razvitie kriogeniki na Ukraine [The development of cryogenics in Ukraine]. Kyiv. 3-4. [in Russian].

3. Tolok, V. T., Cogan, V. S. and Vlasov, V. V. (2009). Fizika i Kharkov [Physics and Kharkov]. Kharkov. 408. [in Russian].

4. (1978). 50 let Kharkovskomy fiziko-technicheskomy instityty [50 years to Kharkov Institute of Physics and Technology]. Kyiv. 319. [In Russian].

5. Dmitrenko, I. M. (1998). Rozdenie instityta (ocherki stanovlenia FTANT AN USSR) [The birth of the institute (essays becoming ILTPE of NASU)]. Kharkov. 138. [in Russian].

6. Eremenko, V. V. and Svechkarev, I. V. eds. (2007). B.I. Verkin, kak my ego pomnim [B. I. Verkin, as we remember it]. Kyiv, 384. [in Russian].

7. (1984). Spravki $i$ informatsii otdela nauki $i$ uchebnih zavedenii, ekonomicheskogo otdela ZK kompanii Urkaini, Soveta ministrov USSR, Donetskogo jbkoma partii, AN USSR, dr. organisazii o rabote partkoma FTINT AN USSR, instituta ypravlenia narodnum hoziaistvom, vstrechah rabotnikov donerskogo obkoma partii so studencheskoi molodezu i dr. voproam nauki i obrazovania (17.01.1984-25.12.1984) 
[Information and information of the department of science and educational institutions, the economic department of the Central Committee of the Communist Party of Ukraine, the Council of Ministers of the USSR, the Donetsk regional committee of the party, the Academy of Sciences of the Ukrainian SSR, other organizations on the work of the Party Committee of the FTINT Academy of Sciences of the USSR, the Institute of National Economy, meetings of the Donetsk regional committee of the party with student youth, other issues of science and education (17.01.1984 - 25.12.1984)]. Tsentralnyi derzhavnyi arkhiv hromadskykh obiednan Ukrainy (TsDAGO Ukrainy) [Central State Archive of Public Associations of Ukraine (CSAPA of Ukraine)], f. 1, op. 25, spr. 2725, ark. 40. [in Russian].

8. (1961). Otchet FTINT po capital'nomy stroitelstvu [Scientific's report (1962)]. Naukovo-tekhnichnyi arkhiv Fizyko-tekhnichnoho instytutu nyzkykh temperatur im. B. I. Vierkina NAN Ukrainy (FTINT NAN Ukrainy) [Scientific and Technical Archive of the Physical-Technical Institute of Low Temperatures named after B. I. Verkin of the National Academy of Sciences of Ukraine (PTILT of NAS of Ukraine).], f. 1, op. 1, spr. 15, ark. 8. [in Russian].

9. Ulianov, V. V. (2009). Teogeticheskaia fizika na fizicheskom fakul'tete Harkovskogo universiteta [Theoretical Physics at the Physics Department of the Kharkiv University]. Kharkiv. 40. [in Russian].

10. (1979). Istoria Akademia nauk Ukrainskoi SSR [History of the Academy of Sciences of the Ukrainian SSR]. Kyiv. 835. [in Russian].

11. (1959-1960). Documenti $i$ materialu pro stvorennia FTINT (dopovidni zapusku AN URSR, postanova Radu Ministriv URSR, materialu tosho) (19591960 pp.) [Documents and materials on the creation of the PTILT (memorandums of the Academy of Sciences of the USSR, the decree of the Council of Ministers of the USSR, the decree of the Council of Ministers of the USSR, materials, etc.) (19591960)]. Instytut arkhivoznavstva NBUV (IA NBUV) [Institute of Archival Studies of NBUV (IAS NBUV).], f. 282, op. 1, spr. 10, ark. 17. [in Ukrainian].

12. Kopii pisem v ZK KPSS, obkomam KPSS, KP Ukraini I drugim organizatsiam, pisma, dokladnie zatiski obkomov KP Ukraini. Sovnarhozov, zavodov I drugih organizatsii - o rabote zavodov, o kapitalnom stroitelstve I drugim voprosam oboronnoi promuschlennosti (1 avgusta 1963 - 29 decabria 1963) [Copies of letters to the Central Committee of the Communist Party of the Soviet Union, regional committees of the CPSU, Communist Party of Ukraine and other organizations, letters, memoranda of the regional committees of the Communist Party of Ukraine. Economic councils, factories and other organizations - on the work of factories, on capital construction and other issues of the defense industry]. TsDAGO Ukrainy [CSAPA of Ukraine)], f. 1. Op. 24. Spr. 4924, ark. 216. [in Russian].

13. Donetskomy fiziko-tehnitcheskomy institute im. A. A. Galkina - 50 let [Donetsk Institute of Physics and Technology A. A. Galkina - 50 years]. Doneckij fiziko-tehnicheskij institut im. A. A. Galkina [Donetsk Institute of Physics and Technology A. A. Galkina]. http://www.donfti.ru/main/donetskomu-fizikotehnicheskomu-institutu-im-a-a-galkina-50-let/ (last accessed : 23/05/2017). [in Russian]. 
14. Varuchin, V. N., Kamenev, V. I. and Krivoruchko, V. N. (2014). Alexandr Alexandrovich Galkin (1914-1982). K stoletiu so dnia rozdenia [Alexander Alexandrovich Galkin (1914-1982). Centenary of birth]. Fizika nizkich temperatur [Physics of low temperature]. 40. 7. 735-736. [in Russian].

15. $K$ istorii kriogennoi laboratorii UFTI NNTs «HFTI» (fragmentu) [To the history of the cryogenic laboratory UPTI NSC «KhPTI» (fragments)]. Nacional'nyj nauchnyj centr HFTI [National Science Center of KhPTI]. https://www.kipt.kharkov.ua/itp/lazarev/2_2_3.html (last accessed : 23/05/2017). [in Russian].

16. (2017). U istokov instituts problem kriobiologii i kriomeditsini [At the origins of the institute of problems of cryobiology and cryomedicine]. Miznarodnii medbchnui zurnal [International Medical Journal]. 3. 93-96. [in Russian].

17. Grichenko, V. I. (2008). Dostizenia kriobiologii I krioneditcini vo imia natsii [Achievements of cryobiology and cryomedicine in the name of nation health]. Problemi kriobiologii [Problems of cryobiology]. 18. 3. 269-274. [in Russian].

18. Prometei v okovah: kak Harkov bul stolitsei tehnologii [Prometheus in chains: how Kharkov was the capital of technology]. http://forbes.net.ua/magazine/forbes/1366094-prometei-v-okovah-kak-harkov-bylstolicej-tehnologij [in Russian]. (last accessed : 23/05/2017).

19. Garbyz, V. I. (1995). Khronika [Chronicle]. Problemi kriobiologii [Problems of cryobiology]. 3. 55-56. [in Russian].

20. (1983). Otchet o nauchno-issledovatellskoi deiatel'nosti FTINT [Report on the research activity of FTINT (1983)]. Naukovo-tekhnicheski archive FTINT NAN Ukraini [Scientific and Technical Archive of the PTILT of NAS of Ukraine], f. 1, op. 1, spr. 1069, ark. 194. [in Russian].

Reviewer:

Irina Borodai,

Doctor of History, Professor

Received: 11/03/2019 